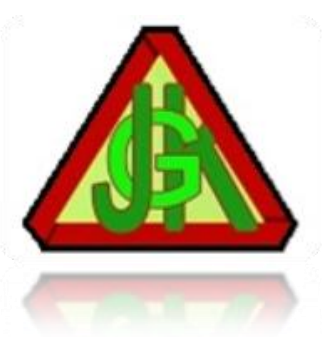

\title{
KEMAMPUAN TOILET TRAINING MEMILIKI HUBUNGAN DALAM PEMAKAIAN DIAPERS PADA ANAK USIA TODDLER
}

\author{
Helena Golang Nuhan ${ }^{1}$, Nyoman Ribek ${ }^{2}$ \\ ${ }^{1}$ Universitas Thamrin \\ Jakarta, Indonesia \\ ${ }^{2}$ Politeknik Kesehatan Kemenkes Denpasar \\ Denpasar, Indonesia
}

email: nuhanhelena@yahoo.co.id ${ }^{1}$,nyomanribek0606@gmail.com ${ }^{2}$

\begin{abstract}
ABSTRAK
Mengajarkan toilet training pada anak tidaklah mudah untuk dilakukannya karena membutuhkan persiapan fisik, psikologis, maupun kognitif pada anak. Kegagalan toilet training dapat disebabkan karena beberapa hal yaitu kurangnya pengetahuan, pemakaian diapers, terjadinya sibling blues, dan lain-lainnya. Penelitian ini bertujuan untuk mengetahui adanya hubungan antara pemakaian diapers terhadap kemampuan toilet training pada anak usia toddler. Metode yang digunakan adalah metode deskriptif dengan pendekatan cross sectional yang menggunakan teknik Purposive. Dimana sampel dalam penelitian ini adalah orang tua yang mempunyai anak usia 12-36 bulan, yang dilaksanakan di Poli Anak RSUD Budhi Asih dengan jumlah sampel 106 responden. Data dianalisis menggunakan teknik analisis chi-square. Hasil penelitian menunjukkan bahwa dari 106 responden, sebanyak 38 (55,9\%) pemakaian diapers dalam intensitas rendah $(\leq 16)$ berhasil melatih anak dalam melakukan toilet training dan sebanyak $30(78,9 \%)$ pemakian diapers dalam intensitas tinggi $(\geq 16)$. Didapatkan nilai $P$ value $=0,030$ dan nilai $O R=2,961(95 \% \mathrm{CI}=1,186-7,329)$. Disimpulkan bahwa ada hubungan antara pemakaian diapers terhadap kemampuan toilet training. Artinya kemampuan toilet training memiliki hubungan dalam pemakaian diapers. Disarankan orang tua selalu melatih anak dalam memakai diapers supaya kemampuan toilet trainingnya sesuai dengan aspek tumbuh kembang anak.
\end{abstract}

Kata Kunci : Pemakaian Diapers, Kemampuan Toilet Training, Anak Usia Toddler

\section{ABSTRACT}

Background : Teaching toilet training to children is not easy to do because it requires physical, psychological, and cognitive preparation in children. The failure of toilet training can be caused by several things, namely lack of knowledge, use of diapers, the occurrence of sibling blues, and others. This study aims to determine the relationship between the use of diapers on the ability of 
toilet training in toddler age children. Methods: The method used is a descriptive method with a cross sectional approach that uses purposive techniques. Where the sample in this study is parents who have children aged 12-36 months, which was carried out at the Children's Clinic of Budhi Asih Hospital with a total sample of 106 respondents. Data were analyzed using chi-square analysis technique Results: The research that has been carried out by researchers shows that from 106 respondents, 38 (55.9\%) using diapers in low intensity (< 16) succeeded in training children in toilet training and as many as 30 (78.9\%) using diapers in high intensity (>16). The $P$ value $=0.030$ and the OR value $=2.961(95 \% \mathrm{CI}=$ 1.186-7.329) it can be concluded that there is a relationship between the use of diapers and the ability of toilet training. Conclusion: the results of the above study indicate that most parents still choose to use diapers in the care of their children. Therefore, it is hoped that parents will care more and pay more attention to their children in aspects of child development, one of which is the ability to toilet training

Keywords: Use of Diapers, Toilet Training Ability, Age Children Toddler

\section{PENDAHULUAN}

Usia todller merupakan usia dimana anak diharapkan mampu melakukan penggunaan toilet secra mandiri Kemampuan anak dalam melakukan toilet training disebabkan oleh beberapa hal salah satu sebabnya karena kurangnya pengetahuan tentang cara melatih anak untuk mengontrol buang air kecil atau besar, pemakaian popok sekali pakai (pospak) atau diaper atau pamper, dan terjadinya sibling blues pada anak. Ketiga hal ini merupakan tantangan besar bagi orang tua karena saat ini masih tingginya anak usia toddler yang masih mengalami kesulitan melakukan toilet training secara mandiri,. Jumlah balita yang sulit mengontrol buang air kecil atau besar sampai usia prasekolah sekitar 75 juta anak $^{(1)}$. Toilet training pada anak merupakan salah satu tugas utama orang tua dalam perkembangan anak usia toddler karena pada anak usia ini memiliki kemampuan untuk mengontrol rasa ingin buang air kecil atau besar, sehingga anak tidak akan buang air kecil atau besar secara sembarangan. Perkembangan toddler dapat ditandai dengan meningkatnya kemampuan pada motorik halus dan kasar sekitar usia 1 sampai 5 tahun $^{(2)}$. Keberhasilan dalam melakukan toilet training ini tergantung dengan kesiapan diri pada anak dan keluarga, hal ini dapat ditunjukkan pada anak, apabila anak tersebut dapat memahami cara pengontrolan 
buang air kecil atau besar dan anak dapat merasakan kapan saatnya ingin buang air kecil atau buang air besar ${ }^{(3)}$. Dampak yang paling umum dalam kegagalan toilet training seperti adanya perlakuan atau tuntutan yang ketat dari orang tua kepada anaknya yang dapat mengganggu kepribadian anak di mana anak akan cenderung minder dan tidak percaya diri, anak bersikap keras kepala dan kikir. Hal ini dapat ditunjukkan oleh orang tua yang sering memarahi anak pada saat buang air kecil atau besar dengan sembarangan dan sikap orang tua yang membiasakan anak mengunakan pospak (diaper) saat berpergian. Adapun dampak negatif akibat ketidakdisiplinan dalam melakukan toilet training yaitu akan berpengaruh terhadap kemandirian anak dan meyebabkan efek psikologis, sehingga anak kurang disiplin dan tidak peka terhadap lingkungan sekitarnya dan anak akan melakukan buang air kecil atau besar di sembarang tempat ${ }^{(4)}$. Sebuah penelitian menunjukkan hasil dari 53 anak usia toddler sebanyak 30 orang $(56,6 \%)$ sudah berhasil menerapkan toilet training sedangkan 23 orang $(43,4 \%)$ belum berhasil menerapkan toilet training. Untuk mengetahui keberhasilan anak dalam toilet training yaitu anak sudah dapat membuka celana secara mandiri, anak dapat ke kamar mandi saat anak ingin buang air kecil atau besar. Keberhasilan anak dalam toilet training akan mendorong anak lebih mandiri dan bertanggung jawab. Dalam penelitian ini orang tua sudah berhasil menerapkan toilet training karena kebiasaan orang tua yang mengajari anak dalam latihan toilet training pada usia anak diatas 3 tahun, dimana anak tersebut sudah siap secara fisik, psikologis dan intelektual ${ }^{(5)}$. Fenomena saat ini di kalangan ibu-ibu muda yaitu ibu lebih memilih menggunakan diapers pada anaknya. Diapers adalah popok sekali pakai yang terbuat dari bahan plastik dan campuran bahan kimia yang mempunyai daya serap tinggi untuk menampung air seni dan feses. Dahulu diapers hanya dipakai oleh orang-orang dengan ekonomi menengah keatas, namun kini pemakaian diapers sudah mulai merata dikalangan ibu-ibu muda yang mempunyai anak usia 1-3 tahun. Pemakaian diapers tidak hanya dipakai saat berpergian jauh, namun saat ini pemakian diapers digunakan dalam aktivitas sehari-hari oleh anak karena penggunaan diapers sangat praktis dan memberikan kenyamanan. Padahal dalam penggunaan diapers mempunyai kerugian pada anak diantaranya dapat 
mengganggu perkembangan anak terutama perkembangan psikologis anak, menimbulkan ruam merah, anak akan susah mengontrol hasrat untuk buang air kecil atau besar ${ }^{(4)}$.

Menurut Tahir mengatakan bahwa apabila terlalu sering menggunakan diaper pada anak, maka akan menyebabkan efek psikologis yang kurang baik pada anak . Anak akan sulit untuk mengontrol keinginan untuk buang air kecil atau besar, karena sudah terbiasa dengan pemakaian diapers yang memudahkan anak untuk buang air kecil atau besar dimana saja dan kapan saja. Saat pemakaian diapers dilepas, maka anak harus berusaha lebih keras untuk mengerti kapan dan dimana anak harus buang air kecil atau besar ${ }^{(6)}$.

Sebagian besar anak toddler yang menggunakan diapers sebanyak 39 anak (100\%) diantaranya 27 anak $(69,0 \%)$ positif memiliki perilaku temper tantum (dampak negatif dari pemakaian terhadap toilet training), sedangkan anak yang tidak menggunakan diapers sebanyak 11 anak (100\%) diantaranya 9 anak $(81,12$ $\%$ ) anak tidak memiliki perilaku temper tantum (dampak positif dari pemakaian diapers terhadap toilet training) ${ }^{(4)}$. Penggunaan diapers memperlambat kesiapan toilet training pada toddler didapatkan data bahwa 49 responden dalam penelitian ini hampir setengah nya yaitu $(46,9 \%)$ mempunyai kebiasaan pemakaian diapers selama 12-24 jam/hari sebanyak 23 anak, kemudian sekitar 15 (30,7\%) responden mempunyai kebiasaan pada pemakaian diapers selama kurang dari 12 jam/hari dan responden yang tidak menggunakan diapers sekitar $11(22,4 \%)^{(7)}$. Penggunaan diapers ini dipengaruhi oleh perkembangan zaman yang semakin maju terutama pada bidang teknologi. Oleh karena itu, semakin banyak produk-produk diapers yang bermunculan di iklan, maka semakin mudah orang tua untuk mendapatkan diapers tersebut. Melihat dari data-data dan fenomena diatas, maka peneliti tertarik untuk melakukan penelitian tentang hubungan pemakaian diapers terhadap kemampuan toilet training pada anak usia toddler.

\section{METODE}

Penelitian ini menggunakan desain penelitian deskriptif dengan jenis korelasi dan pendekatan cross sectional, yang dilaksanakann di ruang Poli Anak 
RSUD Budhi Asih. Populasinya adalah semua orang tua yang mempunyai anak usia 12-36 bulan yang masih menggunakan diapersdengan tehnik pengambilan sampel secara purposive sampling, dengan total sampel berjumlah 106 orang. Analisis dalam penelitian ini dilakukan secara univariat dan bivariat. Analisis univariat digunakan untuk menjelaskan variabel karakteristik responden yang meliputi umur, dan jenis kelamin serta gambaran kemampuan pemakaian diaper dan toilet training. Semua data dianalisis dengan tingkat kemaknaan $(\alpha=0.05)$. Analisis bivariat digunakan untuk mengetahui hubungan yang bermakna antara dua variabel. Analisis bivariat yang digunakan adalah uji chi square untuk mengetahui hubungan kemampuan pemakaian diaper dengan toilet training pada anak usia toddler usia 12-36 bulan di ruang Poli Anak RSUD Budhi Asih Jakarta.

\section{HASIL DAN PEMBAHASAN}

\section{Hasil}

Karakteristik responden yaitu orangtua yang mempunyai anakusia 12-36 bulan yang masih menggunakan diapers di ruang Poli Anak RSUD yang telah memenuhi criteria inklusi yang diidentifikasikan berdasarkan umur dan jenis kelamin. Dalam penelitian ini diukur kemampuan pemakaian diapers dan kemampuan melakukan toilet training yang kemungkinan akan berhubungan terhadap hasil penelitian. Hasil analisis masing-masing variabel ditunjukkan sebagai berikut. 
Tabel 1. Karakteristik Responden berdasarkan Usia Anak, Jenis Kelamin Anak, Usia Ibu, Pendidikan Terakhir Ibu, Status Pekerjaan Ibu, dan Status Ekonomi Keluarga) di RSUD. Budhi Asih

\begin{tabular}{|c|c|c|c|}
\hline No. & Variabel & Frekuensi & $\begin{array}{c}\text { Persentase } \\
(\%)\end{array}$ \\
\hline \multirow[t]{3}{*}{1.} & Usia Anak & & \\
\hline & 12-24 Bulan & 41 & $38,7 \%$ \\
\hline & 25-36 Bulan & 65 & $61,3 \%$ \\
\hline \multirow[t]{3}{*}{2.} & Jenis Kelamin Anak & & \\
\hline & Laki-Laki & 17 & $16,0 \%$ \\
\hline & Perempuan & 89 & $84,0 \%$ \\
\hline \multirow[t]{3}{*}{3.} & Usia Ibu & & \\
\hline & 21-35 Tahun & 82 & $77,4 \%$ \\
\hline & 36-45 Tahun & 24 & $22,6 \%$ \\
\hline \multirow[t]{3}{*}{4.} & Pendidikan Terakhir Ibu & & \\
\hline & Pendidikan Rendah & 40 & $32,7 \%$ \\
\hline & Pendidikan Tinggi & 66 & $62,3 \%$ \\
\hline \multirow[t]{3}{*}{5.} & Status Pekerjaan Ibu & & \\
\hline & Tidak Bekerja & 80 & $75,5 \%$ \\
\hline & Bekerja & 26 & $24,5 \%$ \\
\hline \multirow[t]{3}{*}{6.} & Status Ekonomi Keluarga & & \\
\hline & Dibawah UMR & 70 & $66,0 \%$ \\
\hline & Diatas UMR & 36 & $34,0 \%$ \\
\hline
\end{tabular}

Berdasarkan tabel 1 menunjukkan bahwa responden terbanyak pada usia anak 25-36 bulan sebanyak $65(61,3 \%)$ responden, sebanyak 89 (84,0\%) responden berjenis kelamin perempuan, sebanyak $82(77,4 \%)$ responden ibu berusia 21-35 tahun, sebanyak 66 (62,3\%) responden ibu berpendidikan tinggi, sebanyak $80(75,5 \%)$ responden ibu tidak bekerja, dan sebanyak $70(66,0 \%)$ responden memiliki pendapatan dibawah UMR.

Tabel. 2. Distribusi Frekuensi Pemakaian Diapers Pada Anak Usia Toddler

\begin{tabular}{lcc}
\hline \multicolumn{1}{c}{ Variabel } & Frekuensi & Persentase \\
\hline Penggunaan Diapers & & \\
Intensitas Rendah $(\leq 16)$ & 68 & $64,2 \%$ \\
Intensitas Tinggi $(>16)$ & 38 & $35,8 \%$ \\
\hline
\end{tabular}

Berdasarkan tabel 2 didapatkan responden terbanyak adalah pemakaian diapers dalam intensitas rendah (skor total $\leq 16)$ sebanyak $68(64,2 \%)$ responden. 
Helena Golang Nuhan, Nyoman Ribek. Desember 2021. 14 (2): 157-173

Tabel 3. Distribusi Kemampuan Toilet Training Pada Anak Usia Toddler

\begin{tabular}{lcc}
\hline \multicolumn{1}{c}{ Variabel } & Frekuensi & Persentase \\
\hline Kemampuan Toilet Training & & \\
Kurang Berhasil (skor total $\leq$ & 38 & $38,5 \%$ \\
22) & 68 & $64,2 \%$ \\
Berhasil (skor total >22) & 68 & \\
\hline
\end{tabular}

Berdasarkan tabel 3 didapatkan kemampuan toilet training dengan jumlah terbanyak dengan skor total $\geq 22$ sebanyak $68(64,2 \%)$ responden.

Tabel 4.Hubungan Usia Anak Toddler Terhadap Kemampuan Toilet Training

\begin{tabular}{|c|c|c|c|c|c|c|c|c|}
\hline \multirow[t]{3}{*}{ Usia Anak } & \multicolumn{4}{|c|}{$\begin{array}{c}\text { Kemampuan Toilet } \\
\text { Training }\end{array}$} & \multicolumn{2}{|c|}{ Total } & \multirow[t]{3}{*}{ P Value } & \multirow{3}{*}{$\begin{array}{c}\text { OR } \\
(95 \% \\
\text { CI })\end{array}$} \\
\hline & \multicolumn{2}{|c|}{$\begin{array}{l}\text { Tidak } \\
\text { Berhasil }\end{array}$} & \multicolumn{4}{|c|}{ Berhasil } & & \\
\hline & $\mathrm{n}$ & $\%$ & $\mathrm{n}$ & $\%$ & $\mathrm{n}$ & $\%$ & & \\
\hline $\begin{array}{c}\text { Usia anak } \\
\text { dari } 12-24 \\
\text { bulan }\end{array}$ & 13 & $\begin{array}{c}31,7 \\
\%\end{array}$ & 28 & $\begin{array}{c}68,3 \\
\%\end{array}$ & 41 & $\begin{array}{c}100,0 \\
\%\end{array}$ & 0,618 & $\begin{array}{c}0,743 \\
(0,325- \\
1,697)\end{array}$ \\
\hline $\begin{array}{c}\text { Usia anak } \\
\text { dari } 25-36 \\
\text { bulan }\end{array}$ & 25 & $\begin{array}{c}38,5 \\
\%\end{array}$ & 40 & $\begin{array}{c}61,5 \\
\%\end{array}$ & 65 & $\begin{array}{c}100,0 \\
\%\end{array}$ & & \\
\hline
\end{tabular}

Berdasarkan tabel 4.responden yang berhasil dalam kemampuan toilet trainingnya sebanyak $40(61,5 \%)$ pada usia 25-36 bulan dibandingkan dengan usia anak dari 12-24 bulan sebanyak $28(68,3)$. Hasil uji static nilai $p$ value $=0,618$ disimpulkan tidak bermakna atau tidak ada hubungan karena nilai $\mathrm{p}$ valuenya lebih besar dari alfa 0,05 . dan nilai $O R=0,743$ artinya responden yang memiliki usia anak dari 12-24 bulan memiliki resiko akan terhambatnya dalam kemampuan toilet training dibandingkan usia anak dari 25-36 bulan. 
Tabel 5. Hubungan Jenis Kelamin Terhadap Kemampuan Toilet Training

\begin{tabular}{|c|c|c|c|c|c|c|c|c|}
\hline \multirow[t]{3}{*}{$\begin{array}{c}\text { Jenis } \\
\text { Kelamin }\end{array}$} & \multicolumn{4}{|c|}{$\begin{array}{l}\text { Kemampuan Toilet } \\
\text { Training }\end{array}$} & \multicolumn{2}{|c|}{ Total } & \multirow[t]{3}{*}{ P Value } & \multirow{3}{*}{$\begin{array}{c}\text { OR } \\
(95 \% \\
\mathrm{CI})\end{array}$} \\
\hline & \multicolumn{2}{|c|}{$\begin{array}{l}\text { Tidak } \\
\text { Berhasil }\end{array}$} & \multicolumn{2}{|c|}{ Berhasil } & & & & \\
\hline & $\mathrm{n}$ & $\%$ & $\mathrm{n}$ & $\%$ & $\mathrm{n}$ & $\%$ & & \\
\hline Laki-laki & 10 & $\begin{array}{c}58,8 \\
\%\end{array}$ & 7 & $\begin{array}{c}41,2 \\
\%\end{array}$ & 17 & $\begin{array}{c}100,0 \\
\%\end{array}$ & 0,060 & $\begin{array}{c}3,112 \\
(1,073-\end{array}$ \\
\hline Perempuan & 28 & $\begin{array}{c}31,5 \\
\%\end{array}$ & 61 & $\begin{array}{c}68,5 \\
\%\end{array}$ & 89 & $\begin{array}{c}100,0 \\
\%\end{array}$ & & $9,023)$ \\
\hline
\end{tabular}

Berdasarkan tabel 5 diperoleh responden yang berhasil dalam kemampuan toilet trainingnya lebih banyak pada responden berjenis kelamin perempuan sebanyak $61(68,5 \%)$ dibandingkan dengan responden yang berjenis kelamin lakilaki sebanyak $7(41,2 \%)$. Dari hasil uji statistik nilai $p$ value $=0,060$ artinya perbedaan tersebut tidak bermakna, atau tidak ada hubungan karena nilai $\mathrm{p}$ valuenya lebih besar dari alfa 0,05 nilai $O R=3,112$ artinya responden yang memiliki anak perempuan mempunyai peluang 3,11 kali berhasil dalam kemampuan toilet trainingdibandingkan dengan anak laki-laki.

Tabel. 6. Hubungan Usia Ibu Terhadap Kemampuan Toilet Training

\begin{tabular}{|c|c|c|c|c|c|c|c|c|}
\hline \multirow[t]{3}{*}{ Usia Ibu } & \multicolumn{4}{|c|}{$\begin{array}{l}\text { Kemampuan Toilet } \\
\text { Training }\end{array}$} & \multicolumn{2}{|c|}{ Total } & \multirow[t]{3}{*}{ P Value } & \multirow{3}{*}{$\begin{array}{c}\text { OR } \\
(95 \% \\
\text { CI })\end{array}$} \\
\hline & \multicolumn{2}{|c|}{$\begin{array}{c}\text { Tidak } \\
\text { Berhasil }\end{array}$} & \multicolumn{2}{|c|}{ Berhasil } & & & & \\
\hline & $\mathrm{n}$ & $\%$ & $\mathrm{n}$ & $\%$ & & $\%$ & & \\
\hline $\begin{array}{c}\text { Usia } \\
\text { dewasa } \\
\text { awal (21- } \\
35 \text { tahun) }\end{array}$ & 31 & $\begin{array}{c}37,8 \\
\%\end{array}$ & 51 & $\begin{array}{c}62,2 \\
\%\end{array}$ & 82 & $\begin{array}{c}100,0 \\
\%\end{array}$ & 0,593 & $\begin{array}{c}1,476 \\
(0,550- \\
3,961)\end{array}$ \\
\hline $\begin{array}{c}\text { Usia } \\
\text { dewasa } \\
\text { akhir (36- } \\
45 \text { tahun) }\end{array}$ & 7 & $\begin{array}{c}29,2 \\
\%\end{array}$ & 17 & $\begin{array}{c}70,8 \\
\%\end{array}$ & 24 & $\begin{array}{c}100,0 \\
\%\end{array}$ & & \\
\hline
\end{tabular}

Berdasarkan tabel 6 diperoleh responden yang berhasil dalam kemampuan toilet trainingnya lebih banyak pada responden berusia dewasa awal (21-35 tahun) sebanyak $51(62,2 \%)$ dibandingkan dengan responden yang berusia 
dewasa akhir (36-45 tahun) yaitu sebanyak 17 (70,8\%). Dari hasil uji statistik didapatkan nilai $p$ value $=0,593$ artinya perbedaan proporsi tersebut tidak bermakna atau tidak ada hubungan karena nilai $\mathrm{p}$ valuenya lebih besar dari alfa 0,05 . Hasil analisis didapatkan nilai $O R=1,476$ artinya responden yang memiliki usia dewasa akhir (36-45 tahun) mempunyai peluang 1,47 kali berhasil dalam kemampuan toilet training pada anaknya dibanding dengan ibu yang memiliki usia dewasa awal (21-35 tahun).

Tabel 7. Hubungan Pendidikan terakhir Ibu Terhadap Kemampuan Toilet Training Pada Anak Usia Toddler

\begin{tabular}{|c|c|c|c|c|c|c|c|c|}
\hline \multirow{3}{*}{$\begin{array}{l}\text { Pendidikan } \\
\text { Terakhir } \\
\text { Ibu }\end{array}$} & \multicolumn{4}{|c|}{$\begin{array}{l}\text { Kemampuan Toilet } \\
\text { Training }\end{array}$} & \multicolumn{2}{|c|}{ Total } & \multirow[t]{3}{*}{ P Value } & \multirow{3}{*}{$\begin{array}{c}\text { OR } \\
(95 \% \\
\mathrm{CI})\end{array}$} \\
\hline & \multicolumn{2}{|c|}{$\begin{array}{l}\text { Tidak } \\
\text { Berhasil }\end{array}$} & \multicolumn{2}{|c|}{ Berhasil } & & & & \\
\hline & $\mathrm{n}$ & $\%$ & $\mathrm{n}$ & $\%$ & $\mathrm{n}$ & $\%$ & & \\
\hline $\begin{array}{l}\text { Pendidikan } \\
\text { rendah } \\
\text { (SD, SMP) }\end{array}$ & 9 & $\begin{array}{c}22,5 \\
\%\end{array}$ & 31 & $\begin{array}{c}77,5 \\
\%\end{array}$ & 40 & $\begin{array}{c}100,0 \\
\%\end{array}$ & 0,043 & $\begin{array}{c}0,370 \\
(0,153- \\
0,899)\end{array}$ \\
\hline $\begin{array}{l}\text { Pendidikan } \\
\text { tinggi } \\
\text { (SMA, } \\
\text { perguruan } \\
\text { tinggi) }\end{array}$ & 29 & $\begin{array}{c}43,9 \\
\%\end{array}$ & 37 & $\begin{array}{c}56,1 \\
\%\end{array}$ & 66 & $\begin{array}{c}100,0 \\
\%\end{array}$ & & \\
\hline
\end{tabular}

Berdasarkan tabel 7 diperoleh responden yang berhasil dalam kemampuan toilet trainingnya lebih banyak pada responden yang berpendidikan tinggi (SMA, Perguruan Tinggi) yaitu sebanyak $37(56,1 \%)$ dibandingkan dengan responden yang berpendidikan rendah yaitu sebanyak 31 (77,5\%). hasil uji statistik didapatkan nilai $p$ value $=0,043$ artinya perbedaan proporsi tersebut bermakna, nilai $O R=0,370$ artinya responden yang memiliki pendidikan rendah akan beresiko mengalami kesulitan melatih anaknya dalam melakukan toilet training dibandingkan dengan responden yang berpendidikan tinggi. 
Helena Golang Nuhan, Nyoman Ribek. Desember 2021. 14 (2): 157-173

Tabel 8. Hubungan Antara Status Pekerjaan Ibu Terhadap Kemampuan Toilet Training Pada Anak Usia 12-36 Bulan

\begin{tabular}{|c|c|c|c|c|c|c|c|c|}
\hline \multirow{3}{*}{$\begin{array}{c}\text { Status } \\
\text { Pekerjaan } \\
\text { Ibu }\end{array}$} & \multicolumn{4}{|c|}{$\begin{array}{l}\text { Kemampuan Toilet } \\
\text { Training }\end{array}$} & \multicolumn{2}{|c|}{ Total } & \multirow[t]{3}{*}{ P Value } & \multirow{3}{*}{$\begin{array}{c}\text { OR } \\
(95 \% \\
\mathrm{CI})\end{array}$} \\
\hline & \multicolumn{2}{|c|}{$\begin{array}{c}\text { Tidak } \\
\text { Berhasil }\end{array}$} & \multicolumn{2}{|c|}{ Berhasil } & & & & \\
\hline & $\mathrm{n}$ & $\%$ & $\mathrm{n}$ & $\%$ & $\mathrm{n}$ & $\%$ & & \\
\hline Tidak & 33 & 41,3 & 47 & 58,8 & 80 & 100,0 & 0,072 & 2,949 \\
\hline $\begin{array}{l}\text { Bekerja } \\
\text { Bekerja }\end{array}$ & 5 & $\begin{array}{c}\% \\
19,2 \\
\%\end{array}$ & 21 & $\begin{array}{c}\% \\
80,8 \\
\%\end{array}$ & 26 & $\begin{array}{c}\% \\
100,0 \\
\%\end{array}$ & & $\begin{array}{c}(1,009- \\
8,615)\end{array}$ \\
\hline
\end{tabular}

Berdasarkan tabel 8 diperoleh responden yang berhasil dalam kemampuan toilet trainingnya lebih banyak pada responden yang tidak bekerja yaitu 47 $(58,8 \%)$ dibandingkan dengan responden yang bekerja yaitu $21(80,8 \%)$. Dari hasil uji statistik nilai $p$ value $=0,072$ artinya perbedaan proporsi tersebut tidak bermakna atau tidak ada hubungan karena nilai $\mathrm{p}$ valuenya lebih besar dari alfa 0,05 , nilai $O R=2,949$ artinya responden yang tidak bekerja mempunyai peluang 2,94 kali berhasil dalam kemampuan toilet training pada anaknya dibandingkan dengan responden yang bekerja.

Tabel 9. Hubungan Status Ekonomi Keluarga Terhadap Kemampuan Toilet Training Pada Anak Usia Toddler

\begin{tabular}{|c|c|c|c|c|c|c|c|c|}
\hline \multirow{3}{*}{$\begin{array}{c}\text { Status } \\
\text { Ekonomi } \\
\text { Keluarga }\end{array}$} & \multicolumn{4}{|c|}{$\begin{array}{l}\text { Kemampuan Toilet } \\
\text { Training }\end{array}$} & \multicolumn{2}{|c|}{ Total } & \multirow[t]{3}{*}{ P Value } & \multirow{3}{*}{$\begin{array}{c}\text { OR } \\
(95 \% \\
\mathrm{CI})\end{array}$} \\
\hline & \multicolumn{2}{|c|}{$\begin{array}{l}\text { Tidak } \\
\text { Berhasil }\end{array}$} & \multicolumn{2}{|c|}{ Berhasil } & & & & \\
\hline & $\mathrm{n}$ & $\%$ & $\mathrm{n}$ & $\%$ & $\mathrm{n}$ & $\%$ & & \\
\hline $\begin{array}{c}\leq 3 \\
800.000 \\
\text { (dibawah } \\
\text { UMR) }\end{array}$ & 26 & $\begin{array}{c}37,1 \\
\%\end{array}$ & 44 & $\begin{array}{c}62,9 \\
\%\end{array}$ & 70 & $\begin{array}{c}100,0 \\
\%\end{array}$ & 0,862 & $\begin{array}{c}1,182 \\
(0,507- \\
2,735)\end{array}$ \\
\hline $\begin{array}{l}3.800 .000 \\
\text { (diatas } \\
\text { UMR) }\end{array}$ & 12 & $\begin{array}{c}33,3 \\
\%\end{array}$ & 24 & $\begin{array}{c}66,7 \\
\%\end{array}$ & 36 & $\begin{array}{c}100,0 \\
\%\end{array}$ & & \\
\hline
\end{tabular}


Berdasarkan tabel 9. diperoleh responden yang berhasil dalam kemampuan toilet trainingnya lebih banyak pada responden yang memiliki penghasilan $\leq 3$. 800.000 yaitu $44(62,9 \%)$ dibandingkan dengan responden yang memiliki penghasilan > 3.800.000 sebanyak $24(66,7 \%)$. Dari hasil uji statistik didapatkan nilai $p$ value $=0,862$ artinya perbedaan proporsi tersebut tidak bermakna. atau tidak ada hubungan karena nilai $\mathrm{p}$ valuenya lebih besar dari alfa 0,05nilai dan nilai $O R=1,182$ artinya responden yang memiliki status ekonomi keluarga dengan pendapatan $\leq 3.800 .000$ mempunyai peluang 1,18 kali berhasil dalam kemampuan toilet training pada anaknya dibandingkan dengan responden yang memiliki status ekonomi keluarga dengan pendapatan $>3.800 .000$

Tabel 10. Hubungan Pemakaian Diapers Terhadap Kemampuan Toilet Training Pada Anak Usia Toddler

\begin{tabular}{|c|c|c|c|c|c|c|c|c|}
\hline $\begin{array}{l}\text { Pemakaian } \\
\text { Diapers }\end{array}$ & \multicolumn{4}{|c|}{$\begin{array}{l}\text { Kemampuan Toilet } \\
\text { Training }\end{array}$} & \multicolumn{2}{|c|}{ Total } & \multirow[t]{3}{*}{ P Value } & \multirow{3}{*}{$\begin{array}{c}\text { OR } \\
(95 \% \\
\mathrm{CI})\end{array}$} \\
\hline $\begin{array}{l}\text { Pada Anak } \\
\text { Usia }\end{array}$ & \multicolumn{2}{|c|}{$\begin{array}{l}\text { Tidak } \\
\text { Berhasil }\end{array}$} & \multicolumn{2}{|c|}{ Berhasil } & & & & \\
\hline Toddler & $\mathrm{n}$ & $\%$ & $\mathrm{n}$ & $\%$ & $\mathrm{n}$ & $\%$ & & \\
\hline $\begin{array}{l}\text { Intensitas } \\
\text { rendah } \\
(\leq 16)\end{array}$ & 30 & $\begin{array}{c}44,1 \\
\%\end{array}$ & 38 & $\begin{array}{c}55,9 \\
\%\end{array}$ & 68 & $\begin{array}{c}100,0 \\
\%\end{array}$ & 0,031 & $\begin{array}{c}2,961 \\
(1,186- \\
7,329)\end{array}$ \\
\hline $\begin{array}{l}\text { Intensitas } \\
\text { tinggi } \\
(>16)\end{array}$ & 8 & $\begin{array}{c}21,1 \\
\%\end{array}$ & 30 & $\begin{array}{c}78,9 \\
\%\end{array}$ & 38 & $\begin{array}{c}100,0 \\
\%\end{array}$ & & \\
\hline
\end{tabular}

Berdasarkan tabel 10 diperoleh responden yang berhasil dalam kemampuan toilet trainingnya lebih banyak pada responden yang pemakaian diapers dalam intensitas rendah $(\leq 16)$ yaitu sebanyak 38 (55,9\%) dibandingkan dengan pemakaian diapers dalam intensitas tinggi (> 16) yaitu sebanyak 30 (78,9\%). Dari hasil uji statistik didapatkan nilai $p$ value $=0,031$ artinya perbedaan proporsi tersebut bermakna atau ada hubungan karena nilai $\mathrm{p}$ valuenya lebih kecil dari alfa 0,05 . Hasil analisis didapatkan pula nilai $O R=2,961$ artinya responden yang memilih memakai diapers dalam intensitas rendah $(\leq 16)$ mempunyai peluang 
2,96 kali untuk mengajarkan anaknya dalam melatih toilet training dibandingkan dengan pemakaian diapers dalam intensitas tinggi $(\geq 16)$.

\section{Pembahasan}

\section{Hubungan Antara Usia Anak dengan Kemampuan Toilet Training}

Dari jumlah total responden sebanyak 106, diperoleh data .responden yang berhasil dalam kemampuan toilet trainingnya sebanyak $40(61,5 \%)$ pada usia 25 36 bulan dibandingkan dengan usia anak dari 12-24 bulan sebanyak $28(68,3)$. Dari hasil uji staticnilai $p$ value $=0,618$ artinya tidak bermakna. Nilai $O R=0,743$ artinya responden yang memiliki usia anak dari 12-24 bulan memiliki resiko akan terhambatnya dalam kemampuan toilet training dibandingkan usia anak dari 25-36 bulan.

Biasanya pada anak usia sekitar 18-24 bulan sudah ditandai dengan adanya kesiapan fisik, psikologis dan intelektual pada anak. Dengan bertambahnya usia kedua otot sfingter tersebut semakin mampu mengontrol rasa ingin buang air kecil dan besar.

\section{Hubungan Antara Jenis Kelamin Anak dengan Kemampan Toilet Training}

Responden yang berhasil dalam kemampuan toilet trainingnya lebih banyak pada responden berjenis kelamin perempuan sebanyak $61(68,5 \%)$ dibandingkan dengan responden yang berjenis kelamin laki-laki sebanyak 7 (41,2\%). Dari hasil uji statistik nilai $p$ value $=0,060$ artinya perbedaan tersebut tidak bermakna, nilai $O R=3,112$ artinya responden yang memiliki anak perempuan mempunyai peluang 3,11 kali berhasil dalam kemampuan toilet training dibandingkan dengan anak laki-laki. Anak laki-laki cenderung lebih lambat dalam mengontrol kandung kemihnya dibandingkan dengan anak perempuan. Hal ini disebabkan karena sistem saraf pada anak laki-laki berkembang lebih lama dari pada anak perempuan, anak perempuan dapat menguasai keinginan buang airnya pada usia 18 bulan, sementara anak laki-laki baru menguasai pada saat berumur 22 bulan ${ }^{(7)}$.

\section{Hubungan Antara Usia Ibu dengan Kemampan Toilet Training}

Hasil analisis yang dilakukan oleh penelitidiperoleh data bahwaproporsi responden yang berhasil dalam kemampuan toilet trainingnya lebih banyak pada 
responden yang berusia dewasa awal (21-35 tahun) yaitu sebanyak 51 (62,2\%) dibandingkan dengan responden yang berusia dewasa akhir (36-45 tahun) yaitu sebanyak 17 (70,8\%). Dari hasil uji statistik continuity didapatkan nilai $p$ value $=$ 0,593 maka dapat disimpulkan bahwa perbedaan proporsi tersebut tidak bermakna. Dari hasil analisis didapatkan pula nilai $O R=1,476$ artinya responden yang memiliki usia dewasa akhir (36-45 tahun) mempunyai peluang 1,47 kali berhasil dalam kemampuan toilet training pada anaknya dibanding dengan ibu yang memiliki usia dewasa awal (21-35 tahun).

Usia merupakan ciri dari kedewasaan fisik pada sesorang, semakin bertambahnya usia akan semakin berkembang pula daya tangkap dan pola pikirnya. Usia sangat berpengaruh pada daya tangkap dan pola pikir pada seseorang $^{(8)}$.

\section{Hubungan Antara Pendidikan Terakhir Ibu dengan Kemampan Toilet Training}

Hasil dari analisis yang dilakukan oleh peneliti diperoleh data proporsi responden yang berhasil dalam kemampuan toilet trainingnya lebih banyak pada responden yang berpendidikan tinggi (SMA, Perguruan Tinggi) yaitu $37(56,1 \%)$ dibandingkan dengan responden yang berpendidikan rendah yaitu 31 (77,5\%). Hasil uji statistik continuity didapatkan nilai $p$ value $=0,043$ maka dapat disimpulkan bahwa perbedaan proporsi tersebut bermakna.Dari hasil analisis didapatkan pula nilai $O R=0,370$ artinya responden yang memiliki pendidikan rendah (SD, SMP) akan beresiko mengalami kesulitan melatih anaknya dalam melakukan toilet training dibandingkan dengan responden yang berpendidikan tinggi (SMA, perguruan tinggi). Menurut Semakin tinggi pendidikan seseorang akan mempengaruhi kesiapan toilet training pada anak. Karena dengan pendidikan yang tinggi ibu semakin mudah paham mengenai konsep toilet training ${ }^{(7)}$. Kemampuan toilet training akan bisa lebih baik bila dilakukan Pendidikan Kesehatan secara terus menerus karena perubahan perilaku akan terjadi bila dilakukan Pendidikan Kesehatan secara efektip dan efisien ${ }^{(9)}$. 


\section{Hubungan Antara Status Pekerjaan Ibu dengan Kemampan Toilet Training}

Hasil dari analisis diperoleh data bahwa proporsi responden yang berhasil dalam kemampuan toilet trainingnya lebih banyak pada responden yang tidak bekerja yaitu sebanyak $47(58,8 \%)$ dibandingkan dengan responden yang bekerja yaitu sebanyak $21(80,8 \%)$. Dari hasil uji statistik continuity didapatkan nilai $p$ value $=0,072$ maka dapat disimpulkan bahwa perbedaan proporsi tersebut tidak bermakna.Dari hasil analisis didapatkan pula nilai $O R=2,949$ artinya responden yang tidak bekerja mempunyai peluang 2,94 kali berhasil dalam kemampuan toilet training pada anaknya dibandingkan dengan responden yang bekerja.

Hasil penelitian yang telah pernah dilakukan oleh seorang peneliti dan hasil penelitian menunjukkan adanya perbedaan yang signifikan, perbedaan ini mungkin dapat terjadi karena adanya perbedaan antara jumlah sampel. Julmah sampel yang digunakan peneliti yaitu 106 responden, sedangkan jumlah sampel yang digunakan yaitu 25 responden ${ }^{(10)}$.

\section{Hubungan Antara Status Ekonomi Keluarga dengan Kemampan Toilet Training}

Hasil analisis diperoleh bahwa proporsi responden yang berhasil dalam kemampuan toilet trainingnya lebih banyak pada responden yang memiliki penghasilan $\leq 3.800 .000$ (dibawah UMR) yaitu 44 (62,9\%) dibandingkan dengan responden yang memiliki penghasilan > 3.800 .000 (diatas UMR) yaitu 24 $(66,7 \%)$. Hasil uji statistik continuity didapatkan nilai $p$ value $=0,862$ maka dapat disimpulkan bahwa perbedaan proporsi tersebut tidak bermakna.Dari hasil analisis didapatkan pula nilai $O R=1,182$ artinya responden yang memiliki status ekonomi keluarga dengan pendapatan $\leq 3.800 .000$ (dibawah UMR) mempunyai peluang 1,18 kali berhasil dalam kemampuan toilet training pada anaknya dibandingkan dengan responden yang memiliki status ekonomi keluarga dengan pendapatan > 3.800.000 (diatas UMR).

Hasil penenelitian yang telah dilakukan oleh peneliti lain menunjukkan adanya perbedaan, perbedaan ini mungkin dapat terjadi karena adanya perbedaan jumlah sampel dan pengkatagorian status ekonomi keluarga. Total sampel yang digunakan oleh peneliti yaitu sebanyak 106 responden. Sedangkan hasil penelitian 
yang dilakukan oleh peneliti lain total sampel yang digunakan yaitu 100 responden. Dan perbedaan ini terdapat juga pada pengkatagorian status ekonomi keluarga. Pada pengkategorian yang dilakukan oleh peneliti yaitu pendapatan $\leq 3$. 800.000 (dibawah UMR) dan pendapatan > 3.800.000 (diatas UMR). Sedangkan hasil penelitian yang dilakukan peneliti lain menggunakan pengkatagorian memiliki penghasilan tinggi, menengah, dan rendah ${ }^{(11)}$.

\section{Hubungan Antara Pemakaian Diapers dengan Kemampan Toilet Training}

Hasil analisis diperoleh bahwa proporsi responden yang berhasil dalam kemampuan toilet trainingnya lebih banyak pada responden yang pemakaian diapers dalam intensitas rendah $(\leq 16)$ yaitu sebanyak $38(55,9 \%)$ dibandingkan dengan pemakaian diapers dalam intensitas tinggi (> 16) yaitu sebanyak 30 (78,9\%). Dari hasil uji statistik continuity didapatkan nilai $p$ value $=0,031$ maka dapat disimpulkan bahwa perbedaan proporsi tersebut bermakna.Dari hasil analisis didapatkan pula nilai $O R=2,961$ artinya responden yang memilih memakai diapers dalam intensitas rendah $(\leq 16)$ mempunyai peluang 2,96 kali untuk mengajarkan anaknya dalam melatih toilet training dibandingkan dengan pemakaian diapers dalam Intensitas tinggi $(\geq 16)$.

Penelitian diatas juga didukung dengan penelitian yang pernah dilakukan tentang Penggunaan Diapers Memperlambat Kesiapan Toilet Training Pada Toddler. Dapat disimpulkan dari hasil uji Rank Spearman di dapatkan nilai $P$ value $=0,000$ maka $\mathrm{H} 0$ ditolak artinya ada hubungan penggunaan diapers dengan kesiapan toilet training pada toddler (18-36 blan) di RW 04 Desa Keboan Anom Kecamatan Gendangan Kabupaten Sidoarjo. Hal tersebut menyatakan bahwa penggunaan diapers yang terlalu lama pada anak dapat mengakibatkan dampak negatif terhadap kesiapan toilet training pada anak. Dikarenakan dengan kebiasaan menggunakan diapers maka seorang anak akan mendapatkan kenyamanan dari kebiasaan tersebut, sehingga membuat anak menjadi sulit dilatih dalam melaksanakan toilet training ${ }^{(7)}$. 


\section{SIMPULAN}

Berdasarkan hasil penelitian, maka dapat disimpulkan bahwa tidak ada hubungan faktor usia anak toddler, jenis kelamin anak, usia ibu, status pekerjaan ibu dan status ekonomi keluarga dengan kemampuan toilet training anak. Faktor yang berhubungan dengan kemampuan toilet training anak adalah pendidikan terakhir ibu dan intensitas pemakaian diapers. Dari kedua faktor tersebut, faktor intensitas pemakaian diapers memiliki hubungan yang paling kuat dengan kemampuan toilet training anak usia toddler.

\section{UCAPAN TERIMA KASIH}

Peneliti mengucapkan terimakasih kepada Direktur dan Kepala Poli Anak RSUD Budhi Asih beserta staff yang telah memberikan izin dan membantu dalam melakukan penelitian ini.

\section{ETHICAL CLEARENCE}

Persetujuan etika penelitian ini diperoleh dari komisi etik penelitian Universitas Thamrin.

\section{DAFTAR RUJUKAN}

1. Istikhomah H, Kirwanto A. Perilaku Ibu Tentang Toilet Training Pada Anak Usia 1-3 Tahun (Henik Istikhomah. Perilaku Ibu Tentang Toilet Train Pada Anaka Usia 1-3 Tahun (Henik Istikhomah. 2018;6(2):87-101.

2. Maidartati, Latif DD. Gambaran Pengetahuan Orangtua Tentang Toilet Training pada Anak Usia Toddler di Puskesmas Pasir Kaliki. J Pengabdi Kpd Masy. 2018;1(1):15.

3. Hidayat A. Pengantar Ilmu Keperawatan Anak 1. Jakarta: Salemba Medika; 2009.

4. Norgitasari S, Qurniyawati E. Pemakaian diapers terhadap perilaku tempertantrum pada anak usia toddler. Glob Heal Sci. 2017;2(2):325-31.

5. Rahayuningsih SI, Rizki M. Kesiapan Anak Dan Keberhasilan Toilet Training Di Paud Dan Tk Bungong Seuleupoek Unsyiah Banda Aceh. Kesiapan Anak Dan Keberhasilan Toilet Train Di Paud Dan Tk Bungong Seuleupoek Unsyiah Banda Aceh. 2012;3(3):274-84.

6. I T. Health dan Safety Keluarga. Jogyakarta: UGM; 2010.

7. Tukhusnah M, Kamariyah N. Penggunaan diapers dapat memperlambat kesiapan toilet training pada anak toddler. 2013;6(2).

8. Notoatmodjo S. Promosi Kesehatan Dan Prilaku Kesehatan. Jakarta: 
Helena Golang Nuhan, Nyoman Ribek. Desember 2021. 14 (2): 157-173

Rineka Cipta; 2012.

9. Ribek N, Mertha M. Evaluasi Program Pendidikan Kesehatan Masyarakat Model Stake di Desa Penglipuuran Kubu Bali. Int J Nat Sci Eng [Internet]. 2017;1(1):35-9. Available from:

https://ejournal.undiksha.ac.id/index.php/IJNSE/article/download/12438/78 05

10. Batuatas R, Trifeni. Pengaruh Peran Ibu Dengan Keberhasilan Toilet Training Pada Anak Usia Toddler Di Play Group Tarbiyatush Shibiyan Mojoanyar Mojokerto. Hosp Majapahit. 2012;4(1):70-82.

11. Lita N. Gambaran Pemakaian Diapers Sekali Pakai Pada Anak Usia Pra sekolah. J Phot. 2017;7(2):47-52. 